\title{
GROUNDWATER PROSPECTING ON THE ONSHORE PORTION OF CAMPOS BASIN, IN MICO Leão Dourado Park, Cabo Frio Municipality, Rio De Janeiro, Brazil, by GPR (GROUND PENETRATING RADAR) METHOD
}

\author{
Miguel Ângelo Mane ${ }^{1, *}$, Alan Freitas Machado ${ }^{1}$, MARCElo dos Santos Salomão ${ }^{1}$ ANd José Cesário ${ }^{2}$
}

1 Universidade do Estado do Rio de Janeiro - UERJ, Faculdade de Geologia, Av. São Francisco Xavier, 524, Maracanã. 20550-013 Rio de Janeiro, RJ, Brazil.migangel@uerj.br; alanfmac@gmail.com; salomao.mss@gmail.com

2 Universidade do Estado do Amazonas, Av. Djalma Batista, 3578, Flores, CEP 69050-010, Manaus, Brazil.jmcesario@gmail.com

*CorResPonding AUTHOR, migangel@uerj.br

Received on 31 November 2016

Received in revised form on 18 December 2016

Accepted on 29 December 2016

Editor:

Maria Virginia Alves Martins, Universidade do Estado do Rio de Janeiro, Brazil
Citation:

Mane, M.A., Machado, A.F., Salomão, M.S., Cesário, J. M. A. G., 2016. Groundwater prospecting on the onshore portion of Campos Basin, in Mico Leão Dourado Park, Cabo Frio Municipality, Rio De Janeiro, Brazil, by GPR (Ground Penetrating Radar) method. Journal of Sedimentary Environments, 1(4): 385-392.

\begin{abstract}
The coastal region of Rio de Janeiro State (Brazil) is strongly influenced by the presence of brackish water in its sedimentary substrate. This study aims to map localities where the intrusion of brackish water in groundwater is taking place and to provide a guiding tool using the Ground Penetrating Radar (GPR) data to search freshwater for social use. The study area is located in Mico Leão Dourado Park, at the northern part of Cabo Frio municipality, Rio de Janeiro State, at $1.5 \mathrm{~km}$ from the coast, onshore to Campos Basin. In this region, the potable water is scarce; therefore, the exploration and use of groundwater constitute an important alternative to the local population.

We obtained one line of Ground Penetrating Radar (GPR) record on 2D profile through 20 meters depth using $100 \mathrm{Mhz}$ antenna in quaternary sedimentary area of the central area of Mico Leão Dourado Park. The method provides variations in the subsoil dielectric discontinuity as a function of GPR electromagnetic wave emission. The brackish water intrusion limited the penetration of GPR waves; thus, at some places, because of the change in conductivity of environment, it was
\end{abstract}

\section{Introduction}

Geophysical methods provide information about subsurface physical properties, its conditions and processes, without the need of excavation or drilling (Annan and not possible to map larger sediment thickness due to those conditions.

Results of this research allowed understanding why freshwater or brackish water is being found in neighboring wells of the study area. The arrangement of the sedimentary layers interleaved with clay lenses allows getting freshwater from holes; and, in places without clay lenses, the wells have brackish water. The layered sedimentary structure seems to delimit the clay lenses which avoid the intrusion of marine water and the salinization of groundwater.

The GPR method proved to be a useful tool for the characterization of the sediment layers on the edges of sedimentary basins, such as in Mico Leão Dourado Park, in Cabo Frio Region.

Keywords: Groundwater prospecting. Ground Penetrating Radar (GPR). Electromagnetic methods. Reflection. 2D GPR Profiles. Sedimentary basin edge.

Cosway, 1992; Annan, 1996). They are divided into active and passive methods. The first ones measure subsurface response to electromagnetic field, electric inductive and seismic energy, while the passive methods measure natural temperature, resistivity or conductivity, gravity and magnetic 
field of Earth (Drahor, 2011). Geophysical methods can also be subdivided into airborne, ground geophysics methods and well drilling methods.

For surface methods, measuring instruments are placed on the ground surface. Moreover, drilling geophysical methods require that wells or holes are installed so the instruments can be placed inside the holes. The airborne methods cover large areas for regional studies and the ground geophysics is most used for delimited target or small survey areas.

GPR is a geophysical method that uses electromagnetic waves with frequencies between 10 and 2,500 MHz, to map structures and shallow geological features of subsurface or to locate buried objects. This method is similar to seismic reflection method and sonar on the physical principle and methodology of the field survey, with one exception: it is based on the reflection of electromagnetic waves. All these methods are useful to locate geological features and structures, although the GPR application has a maximum depth penetration in rocks of about 30 meters. This low penetration is a limitation to the application of the GPR method in some geological surveys. However, the method is practical since the equipment used in GPR is simple in terms of operation and provides rapid results.

\section{Study area}

Mico Leão Dourado Park (Figure 1) is inserted in the coastal area of Cabo Frio Tectonic Domain (Schmitt, 2001). This Tectonic Domain was formed during the Neoproterozoic-Eo-Paleozoic and outcrops in the southeastern part of Ribeira Belt, an orogenic belt with NESW trend, which extends along the Atlantic Margin of South America (Heilbron and Machado, 2003).

Throughout the evolution of South American Continent, NE-SW Ribeira Belt structure superimposed on the NNW orientation of Neoproterozoic Brasilia Belt previously developed, resulting in a complex area of interference between the two belts.

Ribeira Belt stretches over $1400 \mathrm{~km}$ and is inserted into Mantiqueira Tectonic Province. It includes a series of crustal fragments of different ages and tectonic evolution that resulted from the amalgamation of Gondwana Supercontinent. The reconstruction of the paleocontinent shows that Ribeira Belt is part of a large orogenic system developed in response to the convergence between San Francisco and Congo cratons and a possible third Cratonic block (Brito Neves and Cordani, 1991).
RESEARCH PAPER

Heilbron et al. (2004) proposed the latest subdivision for Ribeira Belt, delimiting five tectono-stratigraphic terrains separated by thrust faults and by oblique and transpressive shear zones. These terrains are called Occidental, Paraiba do Sul, Embu, Oriental and Cabo Frio. The collision of these terrains is characterized by the imbrication of crustal blocks verging westward, toward the edge of São Francisco Craton (Figure 2; Heilbron et al., 2004).

The sedimentary structure in the region of Cabo Frio and the proximity to the sea contribute to the occurrence of freshwater and brackish water in nearby areas. But the reason for this is still unknown.

\subsection{Objective of this work}

This work aims to study quaternary sediments at the edge of Campos Basin to identify potential sites to obtain freshwater. Freshwater prospecting is relevant to attend the poor population that live in Mico Leão Dourado Park, at the northern part of Cabo Frio municipality, Rio de Janeiro State area, using the GPR method. The study area is a protected environmental area that has never been investigated before. This work analyses for the first time the structure of the sedimentary layers, using the GPR method to understand the groundwater system in Mico Leão Dourado Park.

\section{Material and methods}

The field data acquisition included the records of the soil response from the electromagnetic wave, coming from emissions of the transmitting antenna every 50 centimeters along pre-established lines within the study area, latitude 22055'56'S and longitude 42 $01^{\prime} 07^{\prime \prime} W$ in Mico Leão Dourado Park, Cabo Frio municipality, Rio de Janeiro state (Brazil, Figure 3). The analyzed length profile was of about $1.10 \mathrm{~km}$ and about $15 \mathrm{~m}$ depth.

The GPR data were acquired with a RAMAC Mala Geoscience GPR, model $100 \mathrm{MHz}$ frequency unshielded antenna, running in continuous mode (Annan and Cosway, 1992). The sampling grid provided an appropriate resolution for unconsolidated sediment environment, as found in Mico Leão Dourado Park.

GPR reflection profiles, commonly called radargrams were obtained by moving the transmitter and receiver antennas with a constant spacing interval. The obtained results allowed acquiring a GPR profile that provides a $2 \mathrm{D}$ profiles and the processed picture of changes in the subsurface dielectric properties as a function of the double time of electromagnetic pulse. 


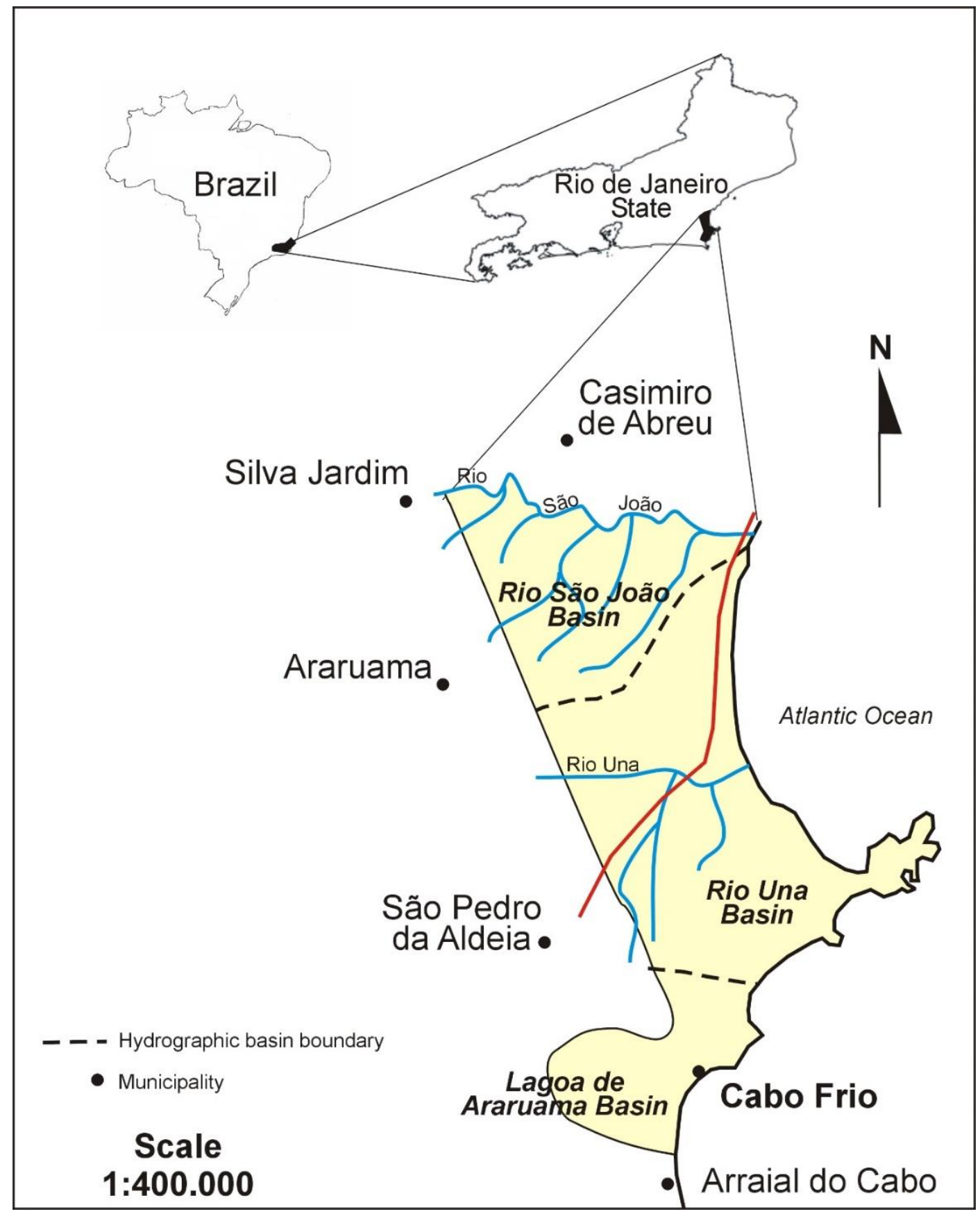

Fig. 1. The yellow area, located in Cabo Frio Municipality, shows the main municipalities watersheds (FEEMA 1988). The blue lines are the main rivers and the red one is the main road. 


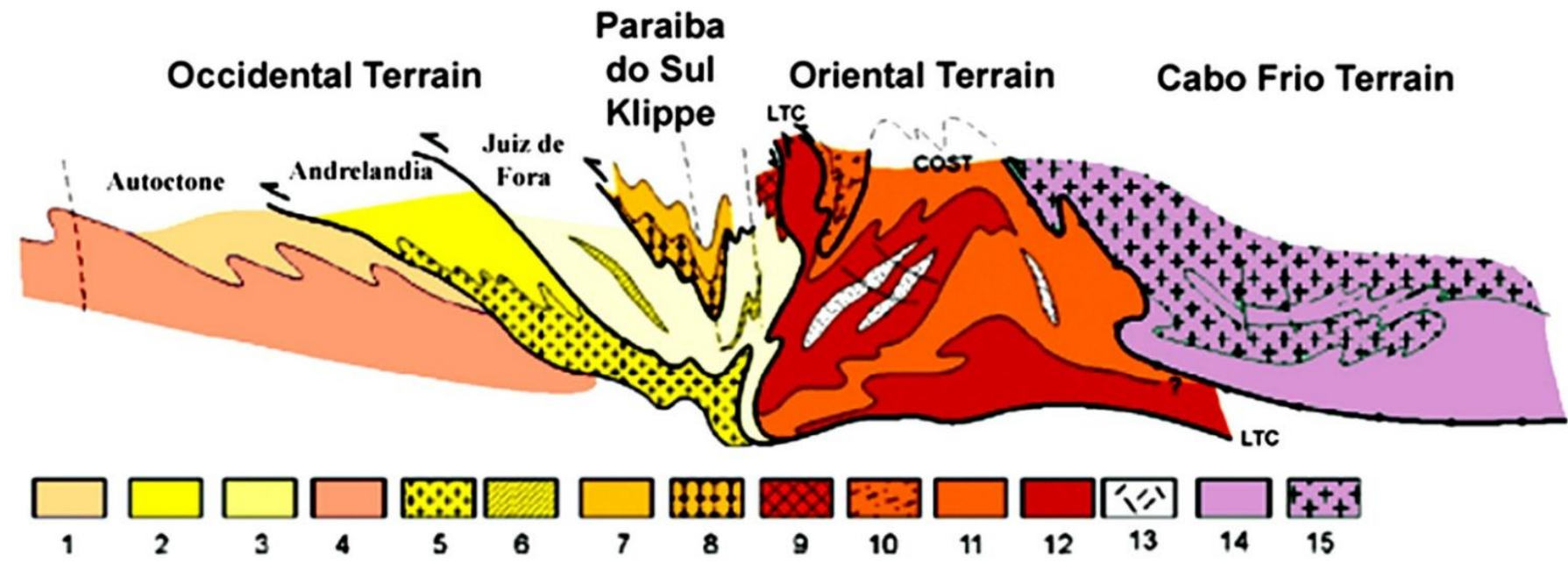

Fig. 2. Structural profile of Ribeira Orogen with the relation between the different terrains and structural domains. Legend: Ocidental Terrain (1-6): 1 to 3 - Megassequence Andrelandia in the domains Autocctone, Andrelandia and Juiz de Fora, Ocidental Terrain; 4 to 6 Associations of the basement (Barbacena, Mantiqueira and Juiz de Fora Complexes); Paraíba do Sul Klippe (7-8): 7- Paraíba do Sul Group; 8- Quirino Complex; Oriental Terrain (9-13): 9- Cambuci Sequence; 10- Italva Sequence; 11- Coastal Sequence; 12- Rio Negro Magmatic Arc; 13-Collisional granites; Cabo Frio Terrain (14-15): 14- Búzios and Palmital Sequences; 15- Região dos Lagos Complex (Heilbron et al., 2004).

The post-field phase encompassed the entire compilation and comparison of data with those from previous work and measurements in the field. This step aimed to promote the knowledge of the shallow geology of the area and the 2D interpretation of GPR profile. The GPR data were processed using the software REFLEX V4.5 of Sandmeier Scientific Software.

The acquisition technique used in this work was the common offset, where a pair of antennas (transmitter and receiver) is displaced along the profile at the same time (Annan, 1996; Figure 4). The traces were acquired every 0.5 meters with 128 signals stacking, scanning 512 samples per trace and $899.6 \mathrm{MHz}$ of sampling frequency and $569.1 \mathrm{~ns}$, for time window. Data processing followed the routine of zero time adjustment, application of temporal filters (Dewow and Bandpass) and enhancement filters (Linear and Exponential; according to Addison et al., 2009).
Figure 4 shows the operating principle of GPR. The reflected energy is recorded based on the travel time (double time), which is amplified, digitized and recorded on the computer's hardware, keeping the data ready for further processing (Annan, 1996).

The physical principle of the method consists in the emission of electromagnetic (EM) waves that are generated by a short pulse of high frequency and are, in turn, repeatedly radiated into the ground by a transmitting antenna. The signal propagation and the depth range of EM waves depend on the frequency emitted and the electrical properties of materials (electrical conductivity, dielectric permittivity and magnetic permeability). Variations in these electrical properties make part of the emitted signal to be reflected; these waves, then reflected and diffracted in subsurface, are received by another antenna also placed on the surface 


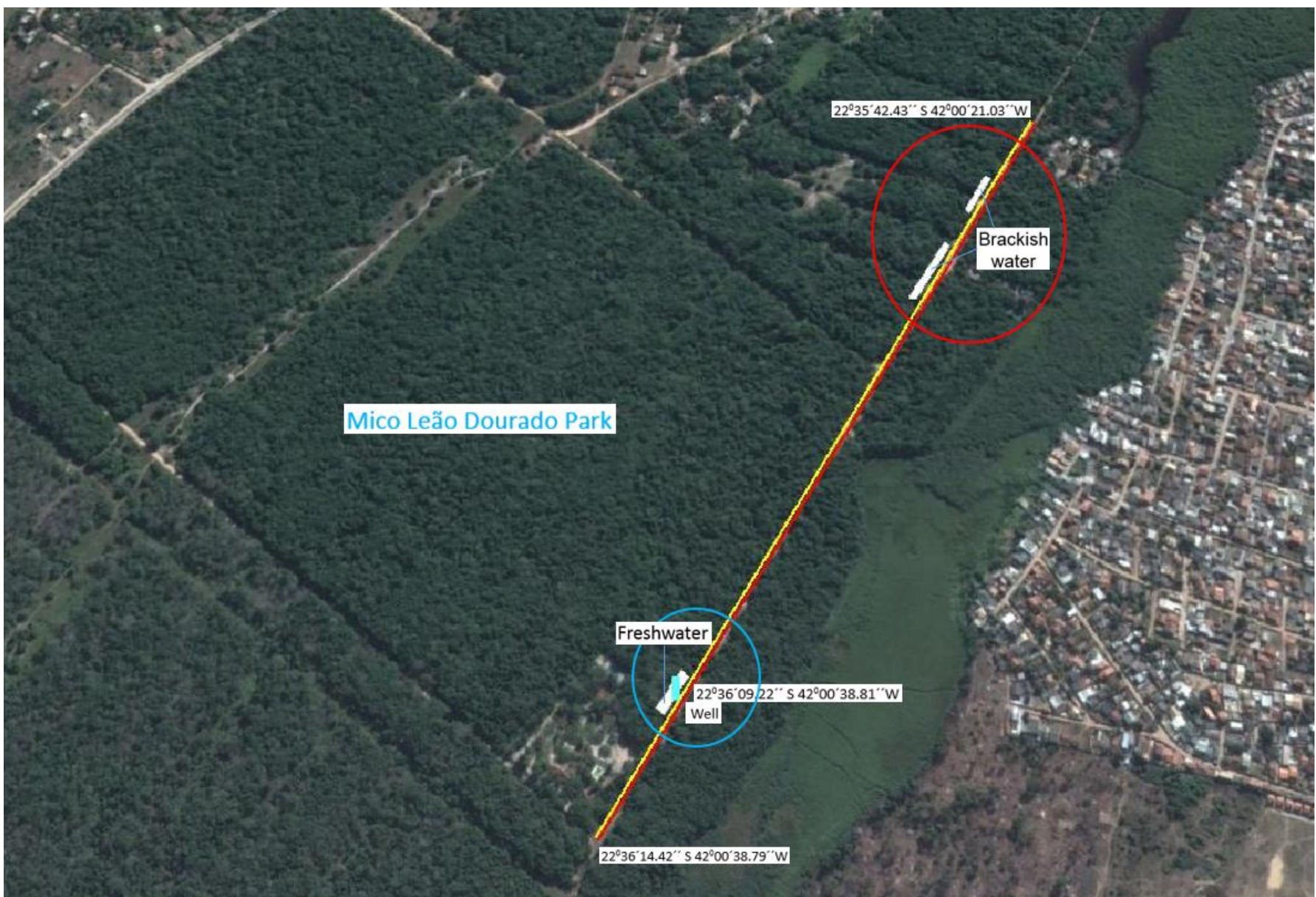

Fig. 3. The GPR analyzed length profile of about $1.10 \mathrm{~km}$ in Mico Leão Dourado Park, Cabo Frio municipality. Adapted from Google Earth. The red area is affected by brackish water and freshwater (the blue area) was found.

\subsection{Theory Background}

The knowledge of the theory and fundamentals of GPR limits are necessary to be able to make a good use of the method for data acquisition. The fundamentals of the GPR method is based on the electromagnetic (EM) wave propagation theory which is supported by Maxwell's equations (Griffiths, 1999; Cook, 2002).

These equations are used to study the Earth's internal structure, from their electrical and magnetic properties, describing the electromagnetic field behavior in any environment. However, they do not provide any information about the electrical properties of the materials where the electric and magnetic fields act. Thus, it is necessary to introduce the constitutive relations of the environment, relating the external electric field applied to the internal field by the electric and magnetic properties of materials.
The EM properties of the materials depend on the composition and humidity of the material. Both variables control the velocity of propagation of EM waves and its attenuation (Annan and Cosway, 1992). The geological materials (sedimentary, metamorphic and igneous rocks) can be considered as semiconductors or dielectrics and can be characterized by three properties: electric conductivity, dielectric permittivity and magnetic permeability.

\section{Results and Discussion}

Figure 5 shows the 2D results obtained in the studied section. The extension of the surveyed line was $1.10 \mathrm{~km}$ approximately, which covers the equivalent to 60 inhabited lots (spatial divisions) by each family, according to the division of small parcels of land. 


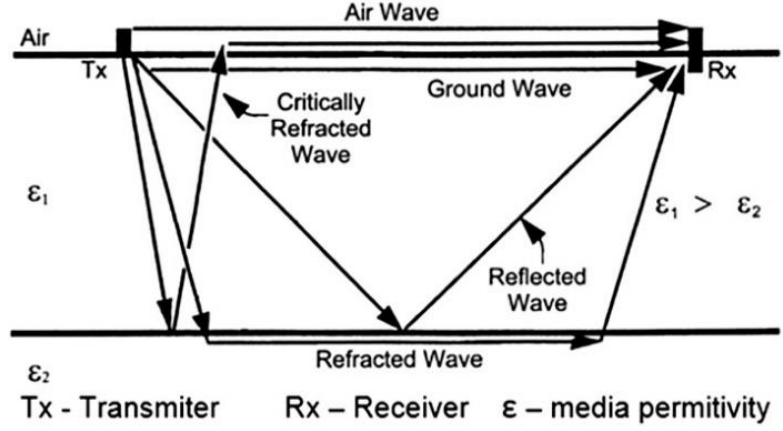

Fig. 4. GPR geometry antenna and wave traject.

These 2D radargram results show the presence of sediment pack whose layers have an apparent dip up to $30^{\circ}$ (Figure 5). Then sediment pack may be composed by littoral sands.

The characteristics of the sub-horizontal sedimentary sequences in the region indicates that the sedimentation events occurred in different stages from the continent towards to the sea and can be attributed to the several transgressions and marine regressions during the Quaternary (Angulo et al., 2002, 2005, 2006, 2008, 2013; Bezerra et al., 2003; Suguio et al., 2005; Tomazelli and Dillenburg, 2007; Castro and Suguio, 2010; Castro et al., 2014).
The GPR results, presented in Figure 5, can be subdivided into two compartments: the first compartment represented by a top sheet that may be seen as the local change soil and possibly quaternary deposits of the region; and the second one, a subjacent layer, suggesting sediment deposition in several steps with an inclination of approximately 30 degrees in $\mathrm{E}-\mathrm{W}$ direction (red lines marked in Figure 5).

In some areas, the bedrock can be discriminated, but the presence of blocks was not observed (Figure 5). However, the GPR results showed clearly layers with superposed interfaces typical of sediments deposition. The mapped subparallel sedimentary layers, with small inclination, are intercalated by clay lens. These clayey lenses serve as a freshwater trap and are suitable places to carry out a survey on wells for water extraction.

Figure 5 shows a well drilled (in a blue marker) where freshwater is being exploited. At a linear distance of 120 to $460 \mathrm{~m}$, freshwater of good quality has been found. At a distance superior to $460 \mathrm{~m}$, the water obtained in wells has brackish characteristics. From this distance the GPR signal was greatly attenuated (Figure 5). The well drilled (4 m deep) is located at the position around 150 meters from the origin of the 2D of GPR profile where freshwater can be exploited (Figure 3).

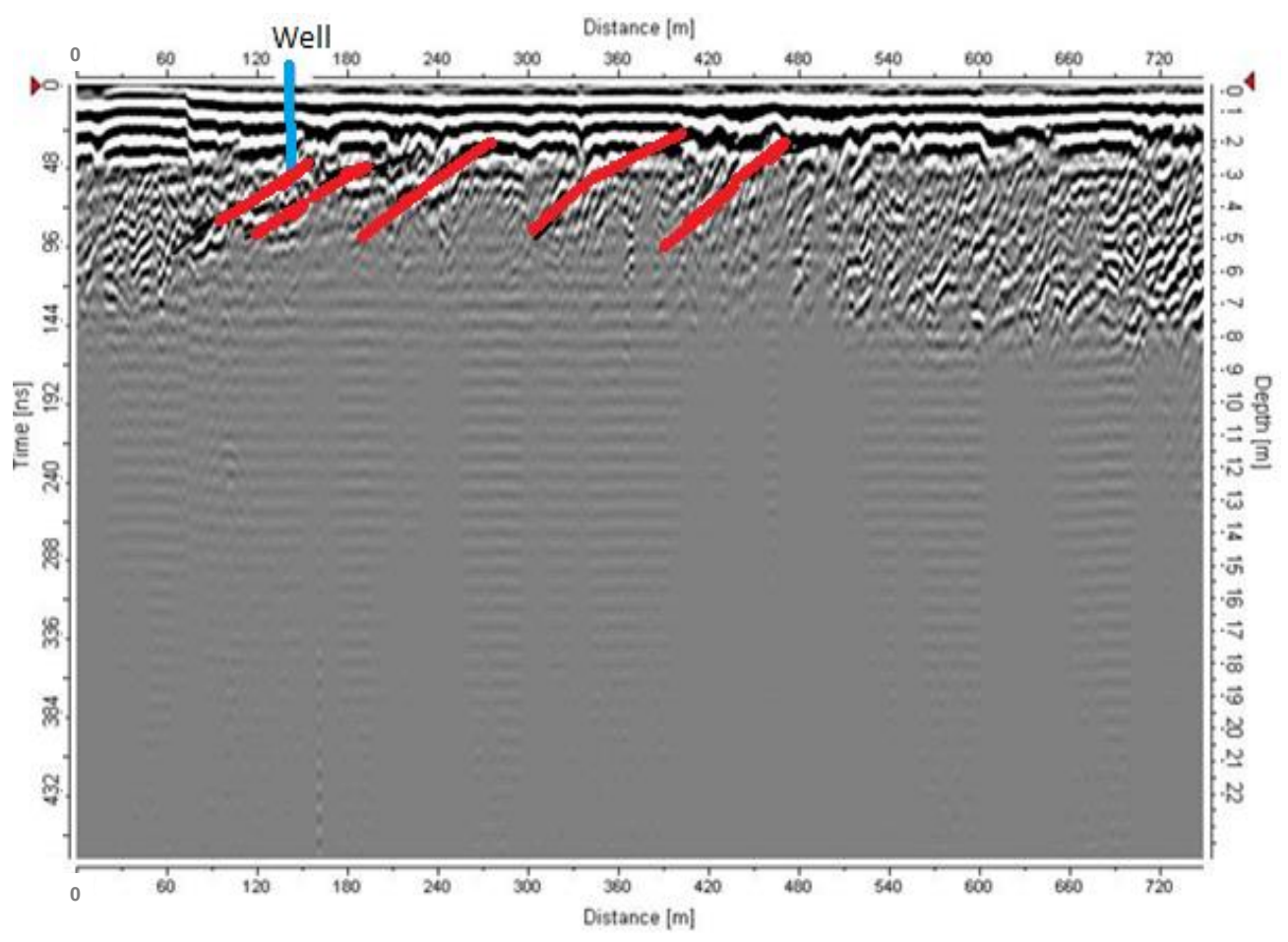

Fig. 5. GPR 2D image showing interpreted dipping layers (in red lines). The location of the well is shown on blue of the figure (coordinates 22.036'09.22”'S, 42.000’38.81' “W). 
Despite some enhancement filters such as $f k$ filters have been used during data processing, the $2 \mathrm{D}$ image did not improve the results of the radar. This may be due to the sedimentary characteristics, which is a common feature in the GPR response in coastal environments.

The freshwater was mapped from the beginning of the line until 150 meters linear into NE direction (Figure 3). From 450 meters linear, the brackish water (Figure 3) blocks the electromagnetic waves.

The results of this study may help the local population to find the best places to drill wells for obtaining freshwater and the local authorities to use the information to the best division of small parcels of land in order to allocate the local population in need.

\section{Conclusion}

The GPR data show a sequence of overlapping layers, poorly defined and inclined, suggesting the direction of dip of these, NE-SW strata. This setting indicates the existence of episodes of sediment deposition in short time intervals and marked by the deposition of thicker sandy facies. This effect corresponds to sea regressions and transgressions at Brazilian coast.

Analyzing GPR 2D profile, we can conclude that the overlap of sedimentary layers with sharp dive and intercalations of clay layers allows, in certain stretches, the existence of wells with freshwater of high quality. In other areas, where the clay layers are absent, the occurrence of wells with brackish water is observed.

The GPR results allowed us to perceive why there is groundwater of good quality and in nearby areas brackish water is found, which cannot be used for human consumption at the northern part of Cabo Frio municipality.

In this work, the electric conductivity of the clays was important to define places where the freshwater can be extracted through wells and places to avoid due to the likely presence of brackish water.

This study showed that the GPR can be an important tool for shallow groundwater research and can help to solve problems related to groundwater exploration in sedimentary areas.

\section{References}

Addison, A., Battista, B.M., Knapp, C., 2009. Improved hydrogeophysical parameter estimation from empirical mode decomposition processed ground-penetrating radar data. Journal of Environmental and Engineering Geophysics, 14 (4) 171-178.

Angulo, R.J., de Souza, M.C., Fernandes, L.A., Disaró, S.T., 2013. Quaternary sea-level changes and aeolianites in the Fernando de Noronha archipelago, northeastern Brazil. Quaternary International 305, 15-30

Angulo, J.R., de Souza, M.C., Assine, M.L., Pessenda, L.C.R., Disaró, S.T., 2008. Chronostratigraphy and radiocarbon age inversion in the Holocene regressive barrier of Paraná, southern Brazil. Marine Geology 252, 111-119.

Angulo, R.J., Lessa, G.C., Souza, M.C., 2006. A critical review of mid- to late-Holocene sea-level fluctuations on the eastern Brazilian coastline. Quaternary Sciense Review 25, 486-506.

Angulo, R.J., Souza, M.C., Reimer, P., Sasaoka, S.K., 2005. Reservoir effect of the southern and southeastern Brazilian coast. Radiocarbon 47, 67-73.

Angulo, R.J., Pessenda, L.C.R., Souza, M.C., 2002. O significado das datações C14 do litoral paranaense na reconstrução de paleoníveismarinhos e na evolução das barreiras do Pleistoceno Superior Holoceno. Revista Brasil Geociências, São Paulo 32 (1), 95-106.

Annan, A. P., Cosway, S.W., 1992. Ground penetrating radar survey design. Symposium on the Application of Geophysics to Engineering and Environmental Problems 2, 329-352.

Annan, A.P., 1996. Transmission dispersion and GPR. Journal of Environmental and Engineering Geophysics, 1 (2), 125-136. doi: 10.4133/JEEG1.B.125

Bezerra, F.H.R., Barreto, A.M.F., Suguio, K., 2003. Holocene sea level history on the Rio Grande do Norte State coast, Brazil. Marine Geology 196, 73-89.

Brito Neves, B.B., Cordani, U.G., 1991. Tectonic Evolution of South America during the Late Proterozoic. Precambrian Research 53, 23-40. doi:10.1016/0301-9268(91)90004-T

Castro, J.W.A., Suguio, K., Seoane, J.C.S., Cunha, A.M., Dias, F.F., 2014. Sea-level fluctuations and coastal evolution in the state of Rio de Janeiro, southeastern Brazil. Anais da Academia Brasileira de Ciências 86(2), 671-683.

Castro, J.W.A., Suguio, K. 2010. Holocene and Late Pleistocene Relative Sea Level Fluctuations in Cabo Frio Island, Rio de Janeiro State - Brazil. In: Congrès Français De Stratigraphia, 4, Strati, Paris (France), p. $58-61$.

Cook, D.M., 2002. The Theory of the Electromagnetic Field. Mineola NY: Courier Dover Publications. p. 335 ff. ISBN 0-48642567-3 
Drahor, M.G., 2011. A review of integrated geophysical investigations from archaeological and cultural sites under encroaching urbanisation in Izmir, Turkey. Physics and Chemistry of the Earth, Parts A/B/C 36, 1294-1309. doi.org/10.1016/j.pce.2011.03.010

Griffiths, D.J., 1999. Introduction to electrodynamics (Third ed.). Prentice Hall. pp. 559-562. ISBN 0-13-805326-X.

Heilbron, M., Pedrosa-Soares, A.C., Campos Neto, M., Silva, L.C., Trouw, R.A.J., Janasi, V.C., 2004. A Província Mantiqueira. In: V. Mantesso-Neto, A. Bartorelli, C.D.R. Carneiro, B.B. Brito Neves (eds.) O Desvendar de um Continente: A Moderna Geologia da América do Sul e o Legado da Obra de Fernando Flávio Marques de Almeida. São Paulo, Ed. Beca, cap. XIII, p. 203-234.
Heilbron, M., Machado, N., 2003. Timing of terrane accretion in the Neoproterozoic-Eo-Palaeozoic Ribeira Orogen (SE Brazil). Precambrian Research 125 (1-2), 87-112.

Schmitt, R.S., 2001. A orogenia Búzios e a evolução tectônica do segmento central da faixa Ribeira. Boletim de Resumos VII Simpósio de Geologia Sudeste, Rio de Janeiro (RJ), vol. 1, 12.

Suguio, K., Angulo, R.J., Carvalho, A.M., Corrêa, I.C.S., Tomazelli, L.J., Vital, H., 2005. Paleoníveis do Mar e Paleolinhas de Costa. In: Oliveira, A.M., Souza, C.R.G.S.; Suguio, K., Oliveira, P.E. Quaternário do Brasil. 1. ${ }^{a}$ ed. Ribeirão Preto: Holos Editora, p.114-129.

Tomazelli, L.J., Dillenburg, S.R., 2007. Sedimentary facies and stratigraphy of a last interglacial coastal barrier in south Brazil. Marine Geology 244, 33-45. 